\title{
The relationship between international crude oil prices and China's refined oil prices based on a structural VAR model
}

\author{
Song Han ${ }^{1} \cdot$ Bao-Sheng Zhang ${ }^{1} \cdot$ Xu Tang ${ }^{1} \cdot$ Ke-Qiang Guo ${ }^{1}$
}

Received: 13 June 2016/Published online: 28 December 2016

(c) The Author(s) 2016. This article is published with open access at Springerlink.com

\begin{abstract}
With the frequent fluctuations of international crude oil prices and China's increasing dependence on foreign oil in recent years, the volatility of international oil prices has significantly influenced China domestic refined oil price. This paper aims to investigate the transmission and feedback mechanism between international crude oil prices and China's refined oil prices for the time span from January 2011 to November 2015 by using the Granger causality test, vector autoregression model, impulse response function and variance decomposition methods. It is demonstrated that variation of international crude oil prices can cause China domestic refined oil price to change with a weak feedback effect. Moreover, international crude oil prices and China domestic refined oil prices are affected by their lag terms in positive and negative directions in different degrees. Besides, an international crude oil price shock has a significant positive impact on domestic refined oil prices while the impulse response of the international crude oil price variable to the domestic refined oil price shock is negatively insignificant. Furthermore, international crude oil prices and domestic refined oil prices have strong historical inheritance. According to the variance decomposition analysis, the international crude oil price is significantly affected by its own disturbance influence, and a domestic refined oil price shock has a slight impact on international crude oil price changes. The domestic refined oil price variance is mainly caused by international crude oil price disturbance, while the domestic refined oil price is slightly affected by its own
\end{abstract}

Bao-Sheng Zhang

bshshysh@cup.edu.cn

1 School of Business Administration, China University of Petroleum, Beijing 102249, China

Edited by Xiu-Qin Zhu disturbance. Generally, domestic refined oil prices do not immediately respond to an international crude oil price change, that is, there is a time lag.

Keywords International crude oil prices · China's refined oil prices · VAR model · Granger causality · Impulse response $\cdot$ Variance decomposition

\section{Introduction}

As an important raw material and energy source in the global industrial economy, petroleum has been playing a key role in promoting the development of the global economy and society (Timilsina 2015). The international crude oil price has a significant impact on China's national economy and the refined oil price level. Figure 1 depicts the variation of international crude oil and China's refined oil prices with time from 2011 to 2015 . The relationship between them deserves to be further explored.

Considering the frequent fluctuation of international oil prices and China's rising dependence on oil imports, more attention has been paid to oil security since it significantly influences the China national economy and public life. However, the China domestic refined oil pricing mechanism is not fully market-oriented and it is subject to direct government control (Liao et al. 2016). Consequently, there is an urgent need for qualitative and quantitative analysis of the relationship between international crude oil prices and domestic oil prices as well as the feedback mechanism (Zhang and Xie 2016; Broadstock et al. 2012; Du et al. 2010). As the China domestic refined oil price has been strongly influenced by the fluctuating international oil price, the current pricing mechanism fails to fully reflect the real supply and demand situation and petrochemical 


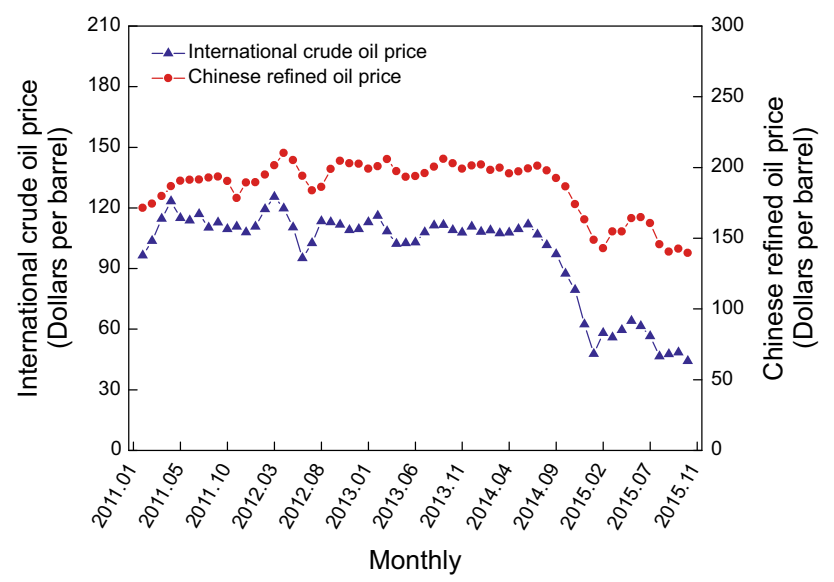

Fig. 1 Variation of international crude oil prices and China's refined oil prices

enterprise costs. Therefore, more factors that influence oil prices should be taken into consideration comprehensively to improve the oil pricing mechanism, so that oil price can reflect the actual supply and demand structure as well as the enterprise costs. What is more, reformation of the refined oil pricing mechanism can lay a solid foundation for future domestic oil market pricing.

Extant research has focused on detailed analysis of relationships between international oil prices and China domestic oil prices.

It is demonstrated that international oil prices not only affect domestic crude oil prices, but also influence the economy in China (Jiang and Jiang 2005). There is a longterm stable relationship between China domestic and international crude oil prices in the quantitative analysis of the price variation during the period of January 1997 to December 2004 (Jiao et al. 2004). Conclusions have been reached that the transmission and feedback mechanism between prices of crude oil and retail refined oil is currently unavailable through an empirical study based on the vector autoregression (VAR) model (Jiang 2013). Statistical test analysis on international crude oil prices and China domestic refined oil prices was conducted to study their interactions, which indicates that there is a structural lag in the international oil price response under the refined oil pricing mechanism in China, and the refined oil pricing mechanism seldom influences the short-term price information transmission (Wang 2014). The anti-symmetry of gasoline/diesel to crude oil price fluctuation is investigated with the anti-symmetry VECM (vector error correction model), and the result demonstrates that the response of gasoline/diesel price to an increase in crude oil price is quick and transient, while the response of gasoline/diesel price to a decrease in crude oil price is delayed and hysteretic (Jiao et al. 2006). It is proposed that the crude oil price is weakly exogenous, its spread is constant in some but not all relationships, and the link between crude oil prices and several refined product prices implies market integration (Asche et al. 2003). Cross-correlations between crude oil and refined product prices based on the wellknown detrended cross-correlation analysis are shown to be significant and strong. Furthermore, multifractality is also revealed in cross-correlations (Liu and Ma 2014).

This paper aims to investigate the transmission and feedback mechanisms between international crude oil prices and China's refined oil from January 2011 to November 2015 by using a Granger causality test, the vector autoregression model, an impulse response function and variance decomposition methods. Understanding of volatility transmission mechanisms is significant for the government to make political decisions. Therefore, the paper provides reasonable suggestions for the policy makers.

The paper is structured as follows. It begins with a data description and a brief introduction of the VAR model in Sect. 2, followed by the empirical analysis in Sect. 3. In Sect. 4, we discuss the results in the context of the Chinese situation and draw some conclusions.

\section{Data and econometric methodology}

\subsection{Data descriptions}

This study sets two variables, the international crude oil prices (IC) and China's refined oil prices (RD). We use monthly spot price data of the Brent crude oil price to represent the international crude oil price and average China national monthly retail price of $-10 \#$ diesel to represent the refined oil price in China. Settings of variables and sources of data are shown in Table 1. Since variable units are not uniform, we have to first normalize the units into US dollars/barrel. According to Volume and Weight of Crude Oil Conversion Table from International Oil Network (http://oil.in-en.com/html/oil-67979.shtml), China's refined oil conversion coefficient is 7.31 barrels/tonne ( $\mathrm{Li}$ and Guo 2013). Then, according to the monthly exchange rate data published by the International Monetary Fund (http://www.imf.org/external/np/fin/data/ param_rms_mth.aspx), we convert the unit of yuan/tonne into the unit of US dollars/barrel.

On March 26, 2009, China's National Development and Reform Commission issued a new refined oil pricing mechanism. However, due to incomplete implementation that caused the information on China's refined oil price to be absent during the period from March 2009 to December 2010, the sample data in this work cover the period from January 2011 to November 2015. In order to eliminate the influence of seasonal factors in the index sequence, we introduce the $\mathrm{X}-13$ Census method to adjust the two 
Table 1 Variable settings and data sources

\begin{tabular}{llcll}
\hline Variable & Definition & Unit & Data sources & $\begin{array}{c}\text { Variable } \\
\text { symbol }\end{array}$ \\
\hline Crude oil price & Brent crude oil price & $\begin{array}{c}\text { Dollars/ } \\
\text { barrel }\end{array}$ & $\begin{array}{c}\text { US Energy Information Administration (http://www.eia.gov/dnav/ } \\
\text { pet/hist/LeafHandler.ashx?n=PET\&s=RBRTE\&f=D) }\end{array}$ & $\begin{array}{c}\text { IC } \\
\text { China Petroleum and Chemical Industry Economic Data }\end{array}$ \\
Refined oil price & $\begin{array}{c}\text { Average national monthly } \\
\text { retail price of -10\# diesel }\end{array}$ & $\begin{array}{c}\text { Yuan/ } \\
\text { tonne }\end{array}$ & $R D$ & \\
\hline
\end{tabular}

variables to make the sequence more realistic and objective. The quantitative analysis software, Eviews8.0, is used in this study to carry out the analysis.

\subsection{Vector autoregressive model}

Without imposing theoretical restrictions on endogeneity among variables, a vector autoregression procedure is appropriate to establish the dynamics between crude oil prices and exchange rates. These two variables are jointly treated as endogenous and are assumed to have no restrictions on the structural relationships in the present analysis.

The VAR is commonly used in systems forecasting interrelated time series and analyzing the dynamic impact of random disturbances on a system of variables. The VAR procedure avoids the need for structural modeling by treating every endogenous variable in the system as a function of lagged values of all of the endogenous variables in the system (Brahmasrene et al. 2014).

The mathematical representation of a VAR model is:

$y_{t}=c_{t}+\sum_{i=1}^{k} \alpha_{i} y_{t-i}+\sum_{i=1}^{k} \beta_{i} x_{t-i}+u_{t}$

where $y_{t}$ is an endogenous variable; $y_{t-i}(i=1,2, \ldots, p)$ is a lagged exogenous variable; $x_{t-i}$ is an endogenous variable; $c_{t}\left(c_{1}, c_{2}, c_{3}, \ldots, c_{t}\right)^{\mathrm{T}}$ is a constant term; $\alpha_{i}$ and $\beta_{i}$ are matrices of coefficients to be estimated; $u_{t}$ is a random disturbance term.

\section{Empirical analysis}

\subsection{Stationary tests of international crude price (IC) and local refined crude price $(\mathrm{RD})$}

The vast majority of econometric models require that economic time series should be stationary. Since most economic variables are non-stationary sequences (Gallagher et al. 2015), it is necessary to implement a stationary test before establishing the model. The standard method of checking sequence stationary is the unit root test $\mathrm{Xu}$ and Lin 2016; Blanco et al. 2013). Table 2 provides the results of unit root tests based on the augmented Dickey-Fuller (ADF) test methods (Dickey and Fuller 1979).

T-statistics values of IC and RD are greater than the critical value of the $10 \%$ test level. Therefore, the test results cannot reject the original hypothesis, which means it is a non-stationary sequence. Then the stationary test of all the variables in the first-order difference is conducted. The augmented Dickey-Fuller (ADF) tests indicate that the null hypothesis of a unit root in the first-order difference can be rejected for all the variables at the $1 \%$ significance level (Table 2). Thus, it can be concluded that all the variables are stationary in the first-order difference and can be conducted with a cointegration test.

\subsection{Cointegration tests of IC and RD}

\subsubsection{The optimal lag order analysis}

A cointegration test is to examine whether there is a longterm stable relationship between variables (Engle and Granger 1987; Bondia et al. 2016; Ouyang and Lin 2015). First of all, we need to establish the VAR model of the two variables and conduct the optimal lag order analysis. We choose a lag of 2 as dictated, and there are five evaluation criteria, namely likelihood ratio test (LR), final prediction error (FPE), Schwartz information criterion (SC), Akaike information criterion (AIC) and Hannan-Quinn information criterion (HQ). Results are given in Table 3.

\subsubsection{Johansen cointegration test}

In this paper, the Johansen test method (Johansen 1988; Johansen and Juselius 1990; Moore and Copeland 1995) is used to carry out the cointegration test, and results are shown in Table 4. Under the assumption that the trace statistic is equal to 6.7905 , the critical value is equal to 15.4947 at the $5 \%$ significance level. The trace statistic value is smaller than the 0.05 critical value, so it cannot reject the original hypothesis that there is no cointegration relationship. Thus, " 0 " in the first column denotes that the null hypothesis of a unit root is rejected at the 5\% significance level. In other words, there is no long-term 
Table 2 Results of ADF unit root tests

\begin{tabular}{llllll}
\hline Series & Test form $(\mathrm{c}, \mathrm{t}, \mathrm{n})$ & T-statistics & Test critical values & Prob.* & Conclusions \\
\hline $\mathrm{IC}$ & $(\mathrm{c}, \mathrm{t}, 0)$ & -1.6733 & $-3.1731^{* * *}$ & 0.7505 & Unstable \\
$\triangle \mathrm{IC}$ & $(\mathrm{c}, \mathrm{t}, 0)$ & -6.0253 & $-4.1273^{*}$ & 0.0000 & Stable \\
$\mathrm{RD}$ & $(\mathrm{c}, \mathrm{t}, 0)$ & -1.7702 & $-3.1739^{* * *}$ & 0.7061 & Unstable \\
$\triangle \mathrm{RD}$ & $(\mathrm{c}, \mathrm{t}, 0)$ & -5.9441 & $-4.1273^{*}$ & 0.0000 & Stable \\
\hline
\end{tabular}

$\triangle:$ First difference of variables

$c$ Constant, $t$ Trend, $n$ Lag order

* The null hypothesis of a unit root is rejected at the $1 \%$ significance level

*** The null hypothesis of a unit root is rejected at the $10 \%$ significance level

Table 3 Results of lag selection criteria

\begin{tabular}{lllllll}
\hline Lag & $\begin{array}{l}\text { Log } \\
\text { likelihood }\end{array}$ & LR & FPE & AIC & SC & HQ \\
\hline 0 & -426.4085 & NA & 26668.4200 & 15.8670 & 15.9407 & 15.8954 \\
1 & -326.6574 & 188.4188 & 769.0211 & 12.3206 & 12.5416 & 12.4059 \\
2 & -305.6141 & $38.18969^{*}$ & $409.4221^{*}$ & $11.6894^{*}$ & $12.0577^{*}$ & $11.8315^{*}$ \\
3 & -302.9547 & 4.629229 & 431.0586 & 11.7391 & 12.2547 & 11.9380 \\
4 & -297.7721 & 8.639171 & 413.9538 & 11.6952 & 12.3582 & 11.9509 \\
5 & -295.0053 & 4.405051 & 435.6073 & 11.7409 & 12.5513 & 12.0535 \\
\hline
\end{tabular}

* The lag order selected by the criterion

Table 4 Results of Johansen cointegration test

\begin{tabular}{|c|c|c|c|c|}
\hline Hypothesized: number of cointegration vectors & Eigenvalue & Trace statistic & 0.05 Critical value & Prob. $^{*}$ \\
\hline 0 & 0.1126 & 6.7905 & 15.4947 & 0.6021 \\
\hline At most 1 & 0.0018 & 0.0991 & 3.8415 & 0.7529 \\
\hline
\end{tabular}

Trace test indicates no cointegration at the 0.05 level

* Mackinnon-Haug-Michelis (1999) $P$ values

stable equilibrium relationship between international crude oil prices and refined oil prices in China.

\subsection{Granger causality tests of IC and RD}

In order to know the price transmission mechanism between the two variables, the Granger causality test method (Granger 1969, 1980) is used to test the causal relationship between variables. Results are shown in Table 5. According to the data, there is significant unidirectional Granger influence of international crude oil prices on China's refined oil prices in the short run, while it is 2nd-order lag and the significance level is $10 \%$.

\subsection{Vector autoregressive models of IC and RD}

The vector autoregressive (VAR) model (Christopher 1980) generalizes the univariate autoregressive model to the multivariate case. This provides beneficial features such as estimation of the dynamic interrelation between variables and indifference about the choice of dependent
Table 5 Results of Granger causality tests

\begin{tabular}{lcl}
\hline Null hypothesis & F-statistic & Prob. \\
\hline RD does not Granger Cause IC & 0.3342 & 0.7174 \\
IC does not Granger Cause RD & 56.5717 & $9 . \mathrm{E}-14^{*}$ \\
\hline
\end{tabular}

variables (Brahmasrene et al. 2014). By applying the optimal model order, Table 6 presents the results of VAR estimates and model diagnostic tests. The results are as follows: $R$-squared $I C=0.9399$, while $R$-squared $R D=0.9717$; Adjusted $R$-squared $I C=0.9353$, while Adjusted $R$-squared $R D=0.9695$. The equations are fitted well, and the overall effect of the model is good.

$$
\begin{aligned}
I C_{t}= & 1.2300 I C_{t-1}-0.1575 I C_{t-2}-0.0535 R D_{t-1} \\
& -0.0496 R D_{t-2}+11.2583 \\
R D_{t}= & 0.8433 I C_{t-1}-0.6977 I C_{t-2}+0.8318 R D_{t-1} \\
& -0.0037 R D_{t-2}+17.7596
\end{aligned}
$$

From Eqs. (2) and (3), it can be seen that two variables are not only affected by their own lags, but also influence 
Table 6 Results of VAR estimates and model diagnostic tests

\begin{tabular}{|c|c|c|c|c|c|}
\hline \multicolumn{3}{|c|}{ Parameter estimates for each equation of the model } & \multicolumn{3}{|c|}{ Test results for each equation of the model } \\
\hline & IC & $\mathrm{RD}$ & $R^{2}$ & 0.9399 & 0.9717 \\
\hline \multirow[t]{3}{*}{$\mathrm{IC}(-1)$} & 1.2300 & 0.8433 & Adj. $R^{2}$ & 0.9353 & 0.9695 \\
\hline & $(0.1425)$ & $(0.0814)$ & Sum sq. residuals & 1916.4000 & 624.4234 \\
\hline & {$[8.6297]$} & {$[10.3660]$} & SE equation & 6.0707 & 3.4653 \\
\hline \multirow[t]{3}{*}{$\mathrm{IC}(-2)$} & -0.1575 & -0.6977 & F-statistic & 203.2994 & 445.6015 \\
\hline & $(0.1813)$ & $(0.1035)$ & Log likelihood & -181.0613 & -149.1022 \\
\hline & {$[-0.8685]$} & {$[-6.7410]$} & Akaike AIC & 6.5285 & 5.4071 \\
\hline \multirow[t]{3}{*}{$\mathrm{RD}(-1)$} & -0.0535 & 0.8318 & Schwarz SC & 6.7077 & 5.5863 \\
\hline & $(0.1782)$ & $(0.1017)$ & Mean dependent & 97.3623 & 186.1442 \\
\hline & {$[-0.3003]$} & {$[8.1787]$} & SD dependent & 23.8619 & 19.8332 \\
\hline \multirow[t]{3}{*}{$\mathrm{RD}(-2)$} & -0.0496 & -0.0037 & \multicolumn{3}{|c|}{ Test of the overall effect of the model } \\
\hline & $(0.1480)$ & $(0.0845)$ & \multicolumn{2}{|c|}{ Determinant residual covariance (dof adj.) } & 415.0074 \\
\hline & {$[-0.3351]$} & {$[-0.0435]$} & \multicolumn{2}{|c|}{ Determinant residual covariance } & 345.3924 \\
\hline \multirow[t]{3}{*}{$\mathrm{C}$} & 11.2583 & 17.7596 & \multicolumn{2}{|l|}{ Log likelihood } & -328.3324 \\
\hline & $(14.4974)$ & $(8.2754)$ & \multicolumn{2}{|c|}{ Akaike information criterion } & 11.8713 \\
\hline & {$[0.7766]$} & {$[2.1461]$} & \multicolumn{2}{|l|}{ Schwarz criterion } & 12.2297 \\
\hline
\end{tabular}

Standard errors in (); T-statistics in []

another variable's lag terms. Influence directions and degrees during different periods are not the same. Among them, according to Eq. (2) for the international crude oil price vector autoregression that the international crude oil price is positively affected by its own 1 period lag term and the influence degree is 1.2300; the international crude oil price is negatively affected by its own 2 period lag term, and the influence degree is 0.1575 . The 1 and 2 period lag terms of domestic refined oil variables have weak and negative impact on the international crude oil price, with respective effects of 0.0535 and 0.0496. Similarly, analytical results of Eq. (3) are obtained. Therefore, the international crude oil price is the primary factor that affects the price of China's refined oil, and the international crude oil price is negatively affected by China's refined oil price. The international crude oil price has a strong historical inheritance. On the other hand, China's refined oil price has weaker historical inheritance. In quantity, if the international crude oil price in the lag last period increased by $1 \%$, the current crude oil price will increase by $1.23 \%$ and China's refined oil price will increase by $0.84 \%$. It is suggested that a rise in the international crude oil price will increase the domestic refined oil price level, and the impact of international oil prices on their own is also very significant.

Overall, the impact of the international crude oil price on China's refined oil price is greater than the impact of the latter on the former. The main reason is that the crude oil is a type of product located in the upstream of the refined oil industry chain (Zhang et al. 2015; Liu and Ma 2014), and the direction of price transmission is mainly transmitted from the international crude oil price to the refined oil price in China. At the same time, the pricing mechanism of China's refined oil is not fully market-oriented and subject to the regulation by a government department. Therefore, there are time lags in terms of price changes.

\subsection{Impulse response functions of IC and RD}

The impulse response function is used to investigate the dynamic effects on the system when a variable is subjected to a certain impact (Xu and Lin 2016). It can be used to analyze the time profile of effects of shocks on the future behavior of international crude oil prices and China's refined oil prices. Figure 2 presents the impulse response for international crude oil prices and China's refined oil prices from one-standard deviation.

According to the above analysis, international crude oil prices and domestic refined oil prices interact with each other in domestic and international crude oil market environments and in the process regulated by the National Development and Reform Commission. A change of the international crude oil price will affect China's refined oil price, and vice versa. In other words, the change of China's refined oil price may also give feedback to the international crude oil price. Therefore, after the establishment of the VAR model, the first step is to analyze the impulse response of China's refined oil price when the international crude oil price is subjected to a shock, results of which are shown in Fig. 2a. The second step is to analyze the impulse 
(a)
Response of RD to nonfactorized
one S.D. IC innovation

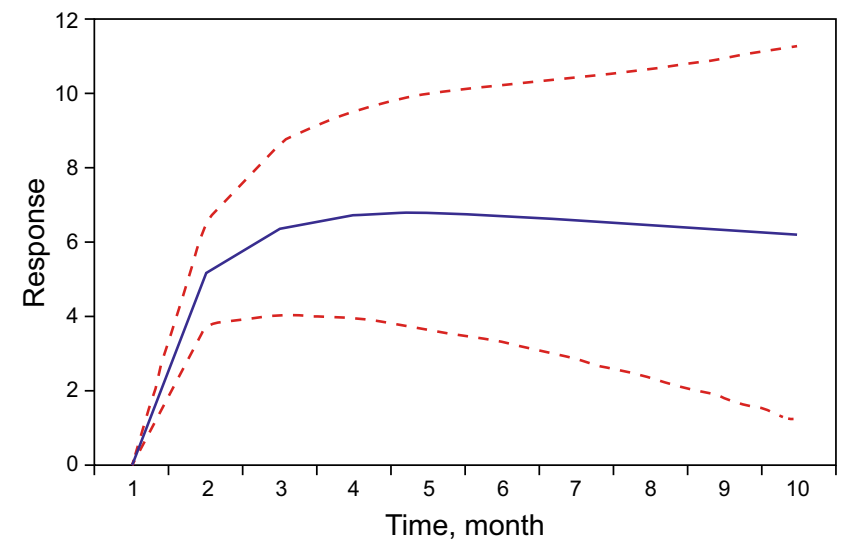

(b)

Response of IC to nonfactorized one S.D. RD innovation

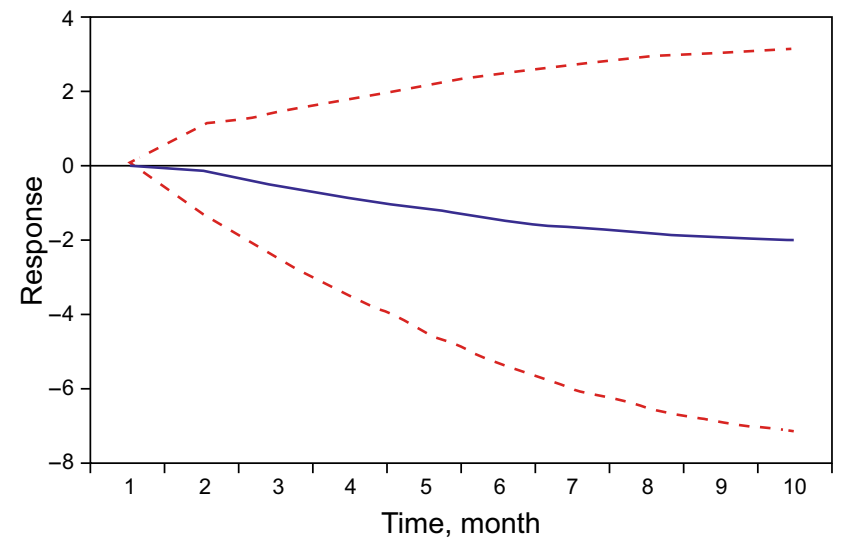

Fig. 2 Impulses response the shock analysis. a Response of RD to IC (The vertical axis represents the dependent variable: RD). b Response of IC to RD (the vertical axis represents the dependent variable: IC). The solid lines indicate mean responses to a one-standard deviation shock, while the dotted lines represent \pm 2 standard deviations of the responses. The horizontal axis represents the number of lag periods of the shock (unit:month).The vertical axis represents the response of relevant dependent variables to independent variable impact

response of international crude oil price when China's refined oil price is subject to a shock, results of which are shown in Fig. 2b.

Figure 2a shows the response of China's refined oil price to an international crude oil price shock. An international crude oil price shock has a significantly positive impact on China's refined oil price. The graph shows that the response of China's refined oil price to a shock in the international crude oil price starts to increase in the first month, and it reaches the maximum value of the impulse response in the fourth month, $7.11 \%$, and then decreases gradually. Figure $2 b$ displays the impulse response of the international crude oil price variable to China's refined oil price shock. The shock has a negative impact on China's refined oil price from the second month and then increases gradually in the negative direction.

It can be concluded through comparison of Fig. 2a and b that the impact of international crude oil price volatility on China's refined oil price is greater than the impact of China's refined oil price volatility on the international crude oil price.

\subsection{Variance decomposition of IC and RD}

Variance decomposition refers to the decomposition of a mean square error of a quantitative shock into the contribution of each variable in the system. Then their contributions are, respectively, calculated to further compute the proportion of their contributions in the total contribution to reflect the relative importance of each variable (Sørensen and Yosha 1998; Hoang and Hoxha 2015).

Table 7 presents results of variance decomposition. A period of ten months is selected to analyze the variance decomposition. Under Columns (3) and (4) in the first month, $100 \%$ of the variability in international crude oil price is explained by its own disruptions. In the subsequent prediction, the variance of the international crude oil price is gradually reduced by its own disruptions, and the part of the domestic refined oil price disruptions gradually increases, but the range is small. This shows that the forecast variance change of international crude oil prices is mainly caused by its own disruptions and the effect is lasting. During the ten months, the influence is generally great, with an average of $98.6 \%$. However, the domestic refined oil price disruption also has a certain impact and the average value is $1.37 \%$. Under Columns (7) and (8) in the first month, $93.8 \%$ of the variability in China's refined oil prices can be explained by its own disruptions and the part of the international crude oil price disruptions is $6.22 \%$.

The variance decomposition of China's refined oil prices has a great change in the second month, of which $64.6 \%$ is attributed to international crude oil price changes, and $35.3 \%$ is attributed to its own disruptions. In the subsequent prediction, the variance of China's refined oil prices is greatly decreased by its own disruptions, while the part of the domestic refined oil price disruptions is gradually enhanced. The results illustrate that the price of refined oil in China is influenced greatly by the change of international crude oil prices. Results of the first and second months show that China's refined oil prices do not change with fluctuations of international crude oil prices, which indicates that the impact of international crude oil price on China's refined oil price is not timely. In this period, the international crude oil price has greater influence with an average of $77.8 \%$, while the domestic refined oil price has a certain influence with the average of $22.2 \%$. 
Table 7 Results of variance decomposition

\begin{tabular}{|c|c|c|c|c|c|c|c|}
\hline \multicolumn{4}{|c|}{ Decompositions of IC } & \multicolumn{4}{|c|}{ Decompositions of RD } \\
\hline (1) Month & (2) SE & (3) IC & (4) RD & (5) Month & (6) SE & (7) IC & (8) RD \\
\hline 1 & 6.0707 & 100.0000 & 0.0000 & 1 & 6.0707 & 6.2228 & 93.7772 \\
\hline 2 & 9.5892 & 99.9650 & 0.0350 & 2 & 9.5892 & 64.6462 & 35.3538 \\
\hline 3 & 12.3826 & 99.7912 & 0.2088 & 3 & 12.3826 & 77.5959 & 22.4041 \\
\hline 4 & 14.6546 & 99.4858 & 0.5142 & 4 & 14.6546 & 83.7041 & 16.2959 \\
\hline 5 & 16.5629 & 99.0815 & 0.9185 & 5 & 16.5629 & 87.2647 & 12.7353 \\
\hline 6 & 18.2085 & 98.6140 & 1.3860 & 6 & 18.2085 & 89.5454 & 10.4546 \\
\hline 7 & 19.6571 & 98.1129 & 1.8871 & 7 & 19.6571 & 91.0556 & 8.9444 \\
\hline 8 & 20.9520 & 97.6006 & 2.3994 & 8 & 20.9520 & 92.0556 & 7.9444 \\
\hline 9 & 22.1230 & 97.0926 & 2.9074 & 9 & 22.1230 & 92.7013 & 7.2987 \\
\hline 10 & 23.1913 & 96.5996 & 3.4004 & 10 & 23.1913 & 93.0957 & 6.9043 \\
\hline
\end{tabular}

\section{Conclusions and policy implications}

This paper aims to investigate the transmission and feedback mechanism between international crude oil prices and China's refined oil prices for the time span from January 2011 to November 2015 by using the Granger causality test, a vector autoregression model, an impulse response function and variance decomposition methods.

It is demonstrated that variation of international crude oil prices causes changes of domestic refined oil prices with a weak feedback effect. Secondly, international crude oil prices and domestic refined oil prices are affected by their lag terms from positive and negative directions in different degrees. Thirdly, an international crude oil price shock has a significant positive impact on domestic refined oil prices while the impulse response of the international crude oil price variable to the domestic refined oil price shock is negatively insignificant. Furthermore, international crude oil prices and domestic refined oil prices have strong historical inheritance. In addition, the international crude oil price is significantly affected by its own distributions. However, a domestic refined oil price shock has a slight impact on international crude oil price changes. The domestic refined oil price variance is mainly caused by international crude oil price distributions and slightly affected by its own distributions. When international crude oil prices change, domestic refined oil prices do not respond in a timely manner to the international crude oil price change, and there exists a time lag.

This study not only effectively complements existing research but also provides important suggestions for policy makers in China. Firstly, the ultimate goal of the refined oil price reform is to establish a market-oriented pricing mechanism in China. For instance, on January 3, 2016, the National Development and Reform Commission issued a report on the further improvement of the oil price formation mechanism to improve the refined oil pricing mechanism. The policy has a certain effect on the stability of national oil prices in the short term. However, for the long-term analysis, fundamentally it cannot solve the pricing problem of the refined oil market in China. Therefore, oil price reform must stick to the principle of integrating the international market price direction. Meanwhile, the establishment of an oil price formation mechanism not only reflects the change of oil prices in the international market but also takes many factors into consideration, such as the domestic market supply and demand, production costs and other social elements. Secondly, it is significant to promote the common development of the oil spot and future market actively. The future market is an open, centralized and unified market, and the oil future price can reflect the market supply and demand to the maximum extent. The development of oil future trading is significant for China, and thus participation in the pricing process of the international oil price is crucial in striving for oil pricing. Chinese enterprises can effectively avoid the risk of oil price fluctuation through oil future trading. Thirdly, the government should improve the system of petroleum reserves in China in the low-price environment, which would be helpful to solve the problem of domestic and international oil price inversion phenomenon and ensure national energy security.

Acknowledgements The authors gratefully acknowledge support from the Key Project of National Social Science Foundation of China (NO. 13\&ZD159). We are also grateful to colleagues from the research laboratory for helpful suggestions that improve this paper.

Open Access This article is distributed under the terms of the Creative Commons Attribution 4.0 International License (http://crea tivecommons.org/licenses/by/4.0/), which permits unrestricted use, distribution, and reproduction in any medium, provided you give appropriate credit to the original author(s) and the source, provide a link to the Creative Commons license, and indicate if changes were made.

\section{References}

Asche F, Gjølberg O, Völker T. Price relationships in the petroleum market: an analysis of crude oil and refined product prices. 
Energy Econ. 2003;25(3):289-301. doi:10.1016/S0140-9883(02) 00110-X.

Blanco JM, Vazquez L, Peña F, et al. New investigation on diagnosing steam production systems from multivariate time series applied to thermal power plants. Appl Energy. 2013;101: 589-99. doi:10.1016/j.apenergy.2012.06.060.

Bondia R, Ghosh S, Kanjilal K. International crude oil prices and the stock prices of clean energy and technology companies: Evidence from non-linear cointegration tests with unknown structural breaks. Energy. 2016;101:558-65. doi:10.1016/j.energy.2016.02.031.

Brahmasrene T, Huang JC, Sissoko Y. Crude oil prices and exchange rates: causality, variance decomposition and impulse response. Energy Econ. 2014;44:407-12. doi:10.1016/j.eneco.2014.05.011.

Broadstock DC, Cao H, Zhang DY. Oil shocks and their impact on energy related stocks in China. Energy Econ. 2012;34(6): 1888-95. doi:10.1016/j.eneco.2012.08.008.

Christopher A. Macroeconomics and reality. Econometrica. 1980;48(1):1-48. doi:10.2307/1912017.

Dickey DA, Fuller WA. Distribution of the estimators for autoregressive time series with a unit root. J Am Stat Assoc. 1979;74(366):427-31. doi:10.1080/01621459.1979.10482531.

Du LM, He YN, Chu W. The relationship between oil price shocks and China's macro-economy: an empirical analysis. Energy Policy. 2010;38(8):4142-51. doi:10.1016/j.enpol.2010.03.042.

Engle RF, Granger CWJ. Co-integration and error correction: representation, estimation, and testing. Econom Soc. 1987;55(2): 251-76. doi:10.2307/1913236.

Gallagher CM, Fisher TJ, Shen J. A Cauchy estimator test for autocorrelation. J Stat Comput Simul. 2015;85(6):1264-76. doi:10.1080/00949655.2013.874424.

Granger CWJ. Investigating causal relations by econometric models and cross- spectral methods. Econometrica. 1969;37(3):424-38. doi: $10.2307 / 1912791$.

Granger CWJ. Testing for causality: a personal viewpoint. J Econ Dyn Control. 1980;2:329-52. doi:10.1016/0165-1889(80)90069-X.

Hoang EC, Hoxha I. Corporate payout smoothing: a variance decomposition approach. J Empir Finance. 2015;35:1-13. doi:10.1016/j.jempfin.2015.10.011.

Jiang CH (2013) An empirical study on the transmission mechanism of the price of crude oil and refined oil retail price in China based on the VAR model during the period of 2003-2011. Macroecon Res. 2013;(4):28-38. doi:10.16304/j.cnki.11-3952/f.2013.04. 001. (in Chinese).

Jiang ZF, Jiang H. China's oil security strategy under the shadow of high oil prices. Modern Manag Sci. 2005;(8):69-70 (in Chinese). doi:10.3969/j.issn.1007-368X.2005.03.030.

Jiao JL, Fan Y, Wei YM. VECM based analysis of gasoline/diesel price anti-symmetry. Manag Sci China. 2006;14(3):97-102. doi:10.16381/j.cnki.issn1003-207x.2006.03.018 (in Chinese).

Jiao JL, Fan Y, Zhang JT, et al. Study of the interactive relationship between Chinese crude oil price and international crude oil price.
Manag Forum. 2004;16(7):48-54. doi:10.14120/j.cnki.cn115057/f.2004.07.009 (in Chinese).

Johansen S, Juselius K. Maximum likelihood estimation and inference on cointegration-with applications to the demand for money. Oxford Bull Econ Stat. 1990;52(2):169-210. doi:10.1111/j.14680084.1990.mp52002003.x.

Johansen S. Statistical analysis of cointegration vectors. J Econ Dyn Control. 1988;12:231-54. doi:10.1016/0165-1889(88)90041-3.

Li ZG, Guo JG. Asymmetry between gasoline and crude oil prices in China based on asymmetric ECM modeling. Resour Sci. 2013;35(1):66-73 (in Chinese).

Liao SJ, Wang FX, Wu T, et al. Crude oil price decision under considering emergency and release of strategic petroleum reserves. Energy. 2016;102:436-43. doi:10.1016/j.energy.2016. 02.043 .

Liu L, Ma GF. Cross-correlation between crude oil and refined product prices. Phys A Stat Mech Appl. 2014;413(1):284-93. doi:10.1016/j.physa.2014.07.007.

Mackinnon JG, Haug AA, Michelis L. Numerical distribution functions of likelihood ratio tests for cointegration. J Appl Econ. 1999;14(5):563-577. doi:10.1002/(sici)1099-1255(199909/10) 14:5<563::aid-jae530>3.3.co;2-i.

Moore MJ, Copeland LS. A comparison of Johansen and PhillipsHansen cointegration tests of forward market efficiency Baillie and Bollerslev revisited. Econ Lett. 1995;47(2):131-5. doi:10. 1016/0165-1765(94)00547-F.

Ouyang XL, Lin BQ. An analysis of the driving forces of energyrelated carbon dioxide emissions in China's industrial sector. Renew Sustain Energy Rev. 2015;45:838-49. doi:10.1016/j.rser. 2015.02.030.

Sørensen BE, Yosha O. International risk sharing and European monetary unification. J Int Econ. 1998;45(2):211-38. doi:10. 1016/S0022-1996(98)00033-6.

Timilsina GR. Oil prices and the global economy: a general equilibrium analysis. Energy Econ. 2015;49:669-75. doi:10. 1016/j.eneco.2015.03.005.

Wang X. Statistical test analysis on the international crude oil prices and domestic refined oil prices to study the interaction relation. Finance Econ. 2014;(4):162-4. doi:10.13546/j.cnki.tjyjc.000153. (in Chinese).

$\mathrm{Xu}$ B, Lin BQ. Assessing $\mathrm{CO}_{2}$ emissions in China's iron and steel industry: a dynamic vector autoregression model. Appl Energy. 2016;161:375-86. doi:10.1016/j.apenergy.2015.10.039.

Zhang J, Xie MJ. China's oil product pricing mechanism: What role does it play in China's macroeconomy? China Econ Rev. 2016;38:209-21. doi:10.1016/j.chieco.2016.02.002.

Zhang T, Ma GF, Liu GS. Nonlinear joint dynamics between prices of crude oil and refined products. Phys A Stat Mech Appl. 2015;419:444-56. doi:10.1016/j.physa.2014.10.061. 